\title{
Transcription factor AP-2 is expressed in neural crest cell lineages during mouse embryogenesis
}

\author{
Pamela J. Mitchell, ${ }^{1,4}$ Paula M. Timmons, ${ }^{2}$, Jean M. Hébert, ${ }^{3}$ Peter W.J. Rigby, ${ }^{2}$ and Robert Tjian ${ }^{1}$ \\ ${ }^{1}$ Howard Hughes Medical Institute, Department of Molecular and Cellular Biology, University of California at Berkeley, \\ Berkeley, California 94720 USA; $^{2}$ Laboratory of Eukaryotic Molecular Genetics, National Institute for Medical Research, The \\ Ridgeway, Mill Hill, London NW7 1AA, UK ${ }^{3}$ Department of Anatomy, University of California at San Francisco, San \\ Francisco, California 94143 USA
}

We have analyzed the expression pattern of transcription factor AP-2 in mouse embryos to evaluate the potential of AP-2 as a regulator during vertebrate development. A partial cDNA encoding AP-2 was isolated from a mouse embryo cDNA library and used to prepare probes to measure AP-2 mRNA levels by RNase protection and RNA in situ hybridization. Between 10.5 and 15.5 days of embryogenesis, the relative abundance of AP-2 mRNA is greatest at $\mathbf{1 1 . 5}$ days and declines steadily thereafter. RNA in situ hybridization analysis of embryos between 8.5 and 12.5 days of gestation identified a novel expression pattern for AP-2. The principle part of this expression occurs in neural crest cells and their major derivatives, including cranial and spinal sensory ganglia and facial mesenchyme. AP-2 is also expressed in surface ectoderm and in a longitudinal column of the spinal cord and hindbrain that is contacted by neural crest-derived sensory ganglia. Additional expression of AP-2 occurs in limb bud mesenchyme and in meso-metanephric regions. This embryonic expression pattern is spatially and temporally consistent with a role for AP-2 in regulating transcription of genes involved in the morphogenesis of the peripheral nervous system, face, limbs, skin, and nephric tissues.

[Key Words: AP-2; transcription factor; mouse embryogenesis; neural crest cells; vertebrate development]

Received September 19, 1990; revised version accepted October 30, 1990.

Insights from invertebrate developmental genetics and from studies in mammalian transcription regulation have facilitated the identification of several gene families that may play important regulatory roles during vertebrate embryogenesis. Foremost among these are the homeo domain and paired-box gene families that encode Hox, POU, and Pax proteins suspected of specifying positional regulatory information (Akam 1989; He et al. 1989; Affolter et al. 1990; Kessel and Gruss 1990); the retinoic acid (RA) receptor genes that encode proteins believed to mediate morphogenetic effects of RA (Evans 1988; Green and Chambon 1988); and the HLH genes (with helix-loop-helix domains) whose products may affect differentiation of cell lineages (Tapscott et al. 1988; Murre et al. 1989|. These diverse proteins share the common feature that they bind specific DNA sequences and regulate expression of particular target genes.

Potential regulatory roles in embryogenesis remain to be assessed for many other sequence-specific DNAbinding proteins that have been newly identified in the context of mammalian transcription regulation studies or by low-stringency cloning strategies using probe sequences from previously cloned DNA-binding regulatory proteins (for review of mammalian DNA-binding

${ }^{4}$ Corresponding author; present address: Institut für Molekularbiologie II der Universität Zürich-Hönggerberg, 8093 Zürich, Switzerland. transcription factors, see Mitchell and Tjian 19891. Some of these candidate developmental regulators belong to multigene families, while others have little or no primary sequence similarity to previously identified vertebrate or invertebrate proteins. To sort out the roles of these factors it is necessary to define their individual fields of action in the organism and the target genes that they regulate within those fields. A first step toward this goal is to analyze the distribution of the factors in adult organisms and in developing embryos. Comparing the expression patterns of many different transcription factors during embryogenesis may suggest possible regulatory cascades and factor interactions that are involved in transcriptional control of vertebrate development (Sassoon et al. 1989; Gaunt and Singh 1990; Kessel and Gruss 1990; Lonai and Orr-Urtreger 1990).

Transcription factor AP-2 was first identified and purified from HeLa cell nuclear extracts by DNA affinity chromatography using an oligonucleotide sequence from the transcriptional enhancer region of the SV40 virus (Mitchell et al. 1987). Purified HeLa AP-2 stimulates RNA polymerase II transcription of test promoters in vitro in an AP-2-binding site-dependent manner. The protein binds sequences with the consensus $5^{\prime}$ GCCCCAGGC-3'; some cellular gene promoters with AP-2-binding sites include human metallothionein-IIA, proenkephalin, collagenase, and murine major histocompatibility complex (MHC) $\mathrm{H}-2 \mathrm{~K}^{\mathrm{b}}$. Isolation of a 
human AP-2 cDNA clone from a HeLa cell cDNA library was accomplished using oligonucleotide probes based on partial peptide sequences of HeLa AP-2 tryptic fragments (Williams et al. 1988). We showed recently that levels of AP-2 mRNA and protein are transiently induced during RA-dependent differentiation of human NT2 teratocarcinoma stem cells into cell types that include neurons (Lüscher et al. 1989). This finding suggested that AP-2 might participate in an RA-activated regulatory cascade during NT2 cell differentiation. A role for RA as a naturally occurring developmental morphogen has been most clearly supported by studies of chick limb skeletal development (Tickle et al. 1985; Eichele 1989); other vertebrate structures found to be developmentally sensitive to retinoid compounds include the nervous system, skin, and skeletal elements of the face (Cohlan 1953; Koplan et al. 1987; Sulik et al. 1988; Sive et al. 1990).

The results presented here suggest that AP- 2 has a role in transcriptional regulation during some retinoid-affected morphogenetic processes, as AP-2 mRNA is found in several embryonic tissues at times when they are known to be developmentally retinoid sensitive. The neural crest, a major source of early AP-2-expressing cell types, has been the subject of a rich tradition of vertebrate experimental embryology (for review, see Le Douarin 1982; Hall 1988). Neural crest cells participate in the morphogenesis of a variety of structures that distinguish vertebrates from invertebrates; and it is believed that the migratory, pluripotent, and inductive features of neural crest cells have played an important part in vertebrate evolution (Maderson 1987). Fate mapping experiments have shown that neural crest-derived cell lineages give rise to much of the peripheral nervous system (sensory and autonomic neurons, glia, and Schwann cells), melanocytes, adrenal medullary cells, several other paraendocrine cell types, and connective tissues, bone, some muscle, and some adipose tissues in the face and ventral neck. There is evidence that cranial neural crest cells are the targets for teratogenic effects of excess RA leading to craniofacial abnormalities; however, molecular mechanisms that direct facial morphogenesis have been elusive (Wedden 1987; Sulik et al. 1988). Analyses of multiple RA receptors (RARs), retinoid-binding proteins, and RA-inducible genes are beginning to shed light on ways that complex patterns of retinoid activities may direct changes in gene transcription that underlie vertebrate morphogenetic processes (Dollé et al. 1989a,b; Eichele 1989; Perez-Castro et al. 1989; Ruberte et al. 1990; Summerbell and Maden 1990). Further investigation of the role of transcription factor AP-2 in this regard may also contribute useful information concerning retinoid-sensitive regulation of vertebrate development.

\section{Results}

\section{Isolation of a murine AP-2 cDNA}

To facilitate analysis of the embryonic expression of AP-2, a murine AP-2 cDNA clone, $\lambda 22$, was isolated

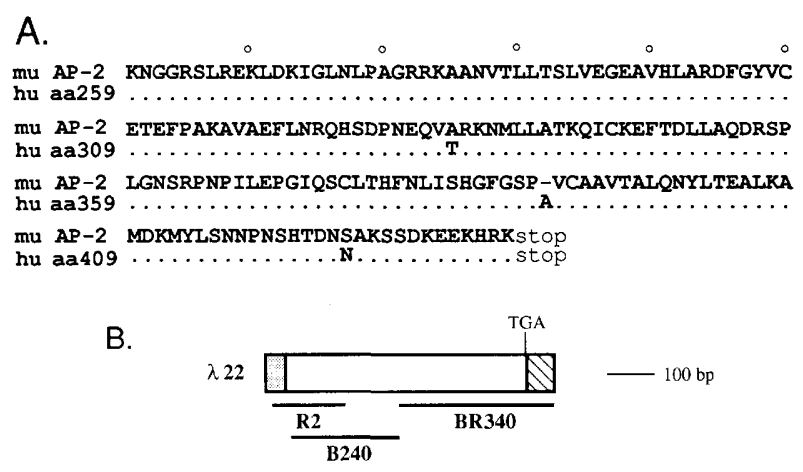

Figure 1. (A) Murine AP-2 partial cDNA (mu AP-2 $\lambda 22$ ) cloned from a 12.5-day mouse embryo cDNA library. The partial amino acid sequence of murine AP- 2 deduced from the DNA sequence of the EcoRI insert in $\lambda 22$ is compared with the homologous carboxy-terminal region of human (hu) AP-2 (cDNA from HeLa cells, amino acids 259-437; Williams et al. 1988). Amino acid differences are noted. $(B)$ Three segments of mu AP-2 were subcloned into pBluescript KS/SK vectors for synthesis of RNA probes used in RNase protection and RNA in situ hybridization experiments. The $\lambda 22$ insert consists of $57 \mathrm{bp}$ of 3 '-untranslated sequence (hatched region) adjacent to $534 \mathrm{bp}$ encoding 178 amino acids of mu AP-2 (open region). A 40-bp segment (shaded region) at the $5^{\prime}$ end of the $\lambda 22$ insert is not homologous to human AP-2 (see Materials and methods, DNA sequencing). The amino acid sequence in $A$ does not include this region. Sequence data have been submitted to the EMBL/ GenBank Data Libraries.

using a 45-base oligonucleotide probe from human AP-2 (Williams et al. 1988) to screen a $\lambda$ gt 10 cDNA library representing 12.5-day mouse embryo mRNA. $\lambda 22$ contains a partial murine AP- 2 cDNA encoding 178 amino acids that are $98 \%$ conserved relative to the carboxy-terminal end of human AP-2 (Fig. 1A). HeLa AP-2 is 437 amino acids in length; the carboxy-terminal 200 amino acids of human AP-2 constitute a novel sequence-specific DNA binding and dimerization domain (T. Williams et al., unpubl.). Southern blot analysis of a panel of somatic cell hybrids has suggested that the human AP-2 gene maps to chromosome 6 near the HLA locus (L. Stubbs, unpubl.).

\section{AP-2 mRNA levels in adult mouse tissues and cultured cell lines}

Amounts of AP-2 mRNA in several cultured cell lines and adult mouse tissues were compared by RNase protection analyses of cytoplasmic RNA samples using an antisense probe for a 145-nucleotide segment of mouse AP-2 (R2 region; Fig. 1B). For reference, antisense probes were also used to measure RNA from Hox-2.1 (Hox-2 gene family member; Hauser et al. 1985) and Dhfr (dihydrofolate reductase, a cell proliferation-linked housekeeping enzyme; Chang et al. 1978). In these experiments, AP-2 mRNA was most abundant in fibroblastic cell lines 3T3, 3T6 (Fig. 2, lanes 1 and 2), and C3H10Tl/2 (not shown). AP-2 was expressed at very low levels in undifferentiated F9 teratocarcinoma stem cells (20-fold less than in 3T3 cells; data not shown) and was not sig- 


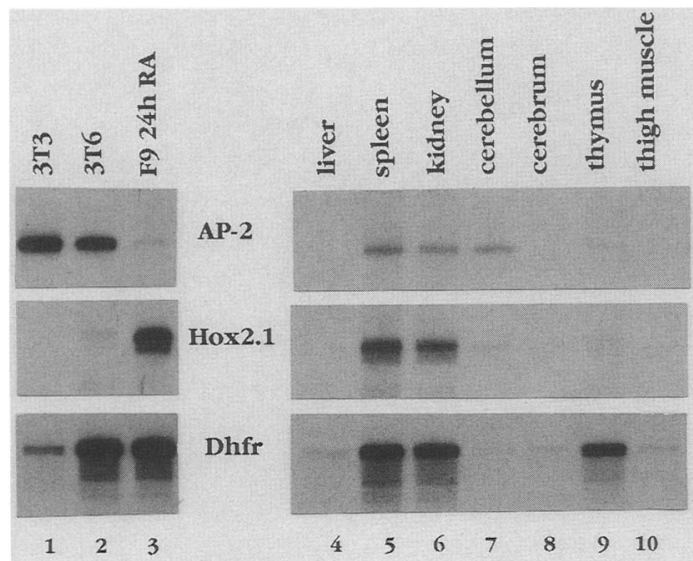

Figure 2. RNase protection analysis to measure AP-2 mRNA levels in several murine cell lines and adult mouse tissues. Each lane represents protected RNA segments obtained after hybridizing $5 \mu \mathrm{g}$ cytoplasmic RNA with AP-2, Hox2.1, and Dhfr antisense RNA probes simultaneously for $16 \mathrm{hr}$ at $63^{\circ} \mathrm{C}$ and digesting with RNase to remove unhybridized RNA (R2 probe for AP-2 was used; Fig. 1B). The gel autoradiograph bands from one experiment have been cut into strips and arranged for easy reference.

nificantly induced during differentiation of F9 cells into extraembryonic endoderm-like cells by treatment with either RA or RA + cAMP (data collected at 24-hr intervals over 7 days not shown, except for 24-hr RA treatment point; Fig. 2, lane 3). Hox-2.1 RNA was undetectable before differentiation of F9 cells, but was dramatically induced after $24 \mathrm{hr}$ of RA treatment (lane 3) and remained elevated over 7 days of treatment.

In adult mouse tissues, AP-2 mRNA was not appreciably detected in liver, cerebrum (Fig. 2, lanes 4 and 8), or heart (not shown) but was observed at low levels in kidney, cerebellum, spleen, and thymus (very low) (lanes $6,7,5$, and 9). These levels were significantly lower than those observed in cultured fibroblasts. Although AP-2 mRNA was not found in a thigh muscle RNA sample that we tested (Fig. 2, lane 10), a low amount was observed in a commercially available mouse skeletal muscle RNA (data not shown).

\section{Temporal and spatial distribution of AP-2 mRNA during mouse embryogenesis}

Poly(A)+ RNA samples from whole mouse embryos between 10.5 and 15.5 days of embryogenesis [or days postcoitus (dpc)] were analyzed by RNase protection. During this period, the relative level of AP- 2 mRNA was greatest at $11.5 \mathrm{dpc}$ and gradually declined thereafter (Fig. 3A). The period between 11.5 and $13.5 \mathrm{dpc}$ represents a dramatic phase of organ and tissue morphogenesis in the mouse. To determine whether AP-2 was region-specifically expressed during embryogenesis, RNA samples prepared from dissected parts of 12.5- and 13.5dpc embryos were analyzed by RNase protection analysis using antisense RNA probes for AP-2 and four reference genes: Hox-2.1, MyoD (Tapscott et al. 1988), Spl
(Kadonaga et al. 1987), and Dhfr (Fig. 3). AP-2 mRNA was distributed in all three parts of dissected 12.5-dpc embryos [central nervous system, face, and body; the CNS is defined as the brain and spinal cord]. The 13.5dpc embryos were dissected into nine parts; here, region-specific differences in AP-2 expression were observed. AP-2 mRNA was most abundant in the hindbrain, spinal cord, face, and limbs; lower levels were seen in the body (carcass). Very low expression of AP-2 was observed in yolk sac, heart/lung, and forebrain;
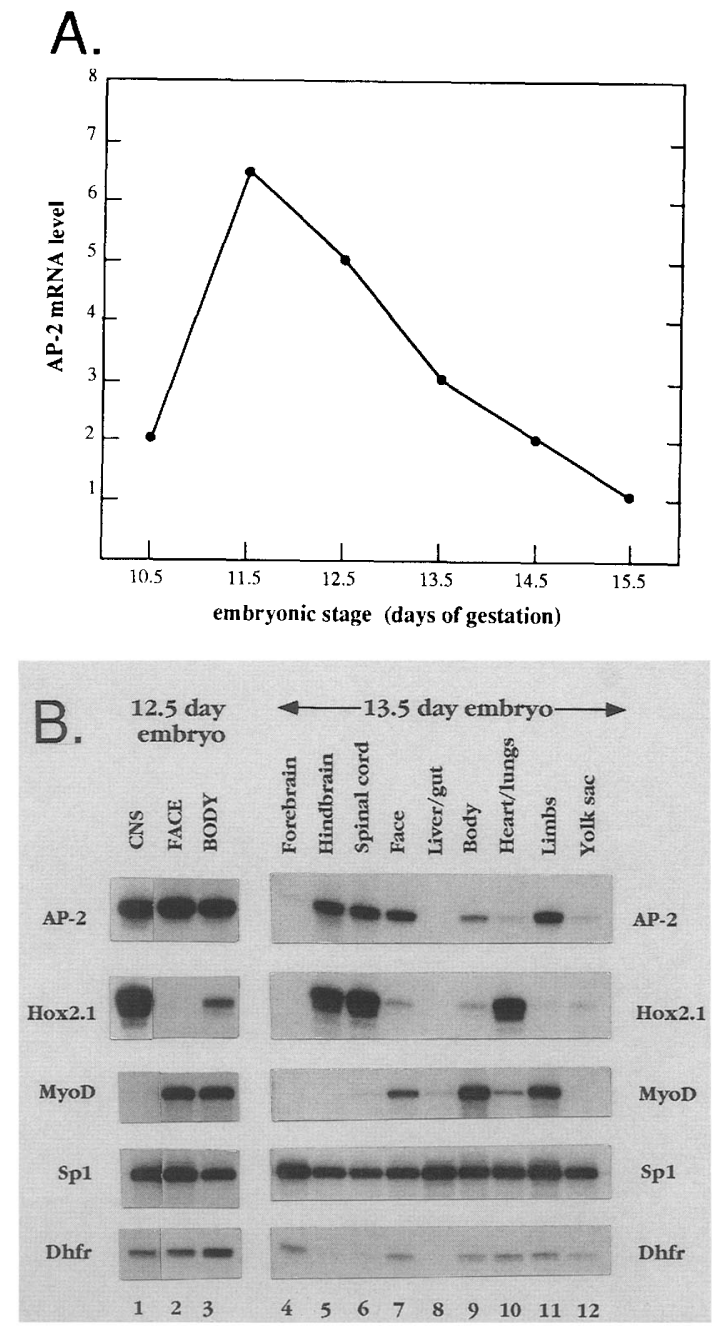

Figure 3. RNase protection analysis to assess relative abundance and region-specific expression of AP-2 mRNA during mid-embryogenesis in the mouse. $\mathrm{R} 2$ region antisense probe for AP-2 was used (Fig. 1B). (A) AP-2 mRNA levels in embryos between 10.5 and $15.5 \mathrm{dpc}$ were compared by RNase protection of $1 \mu \mathrm{g}$ poly $(\mathrm{A})^{+}$RNA samples prepared from whole embryos (total gestation time in mouse is $19.5 \mathrm{dpc}$. The data are summarized graphically from densitometric measurements of gel autoradiographic bands. AP-2 mRNA levels were normalized to $15.5 \mathrm{dpc}=1$; the numbers are arbitrary units. $(B) \mathrm{AP}-2 \mathrm{mRNA}$ levels in tissues and parts of 12.5 - and 13.5 -dpc mouse embryos were compared with those of four reference genes. The 5- $\mu \mathrm{g}$ total cellular RNA samples prepared from dissected embryo parts were tested using antisense probes for AP-2, MyoD, Hox-2.1, Spl, and Dhfr. 
while no expression was detected in the liver/gut compartment. Three of the reference genes (Hox-2.1, MyoD, and $D h f r)$ also exhibited region-specific differences in expression; their individual patterns were different from each other and from AP-2. In marked contrast, mRNA of transcription factor Sp1 was present at very similar levels in all nine parts of 13.5-dpc embryos. These experiments encouraged us to analyze the distribution of AP-2 mRNA during embryogenesis in more detail.

\section{RNA in situ hybridization to embryo sections}

AP-2 expression was analyzed by RNA in situ hybridization to paraffin serial sections of mouse embryos between 7.5 and $12.5 \mathrm{dpc}$. At $7.5 \mathrm{dpc}$ (presomite gastrula), AP-2 mRNA was not detected in the embryo proper, but was expressed extraembryonically in trophoblastic tissue (not shown). At $8.5 \mathrm{dpc}$ (8-12 somite stage), AP-2 mRNA was adundant in the anterior portion of the embryo and also persisted in trophoblastic cells (Fig. 4A,B). Transverse sections through the head revealed strong signal in lateral head mesenchyme and surface ectoderm but little or no expression in the brain plate or the sparse mesenchyme medial to it (Fig. $4 \mathrm{C}, \mathrm{D}$ ). In the posterior body, AP-2 mRNA was detected in surface ectoderm and neural folds but not in the neural plate, somites, or presomitic mesoderm (Fig. 4C,E). The pattern of AP-2
mRNA in neural folds and head mesenchyme at this time closely approximates the spatial distribution of the earliest identified neural crest cells in the mouse embryo (Chan and Tam 1988). Neural crest cells originate in a craniocaudal wave from neural fold neuroectoderm along the lateral margins of the vertebrate neural plate before and during closure of the neural tube. Migrating away from the dorsal axis (LeDouarin 1982; Tan and Morriss-Kay 1986; Chan and Tam 1988), neural crest cells proliferate and collect in multiple locations where they form or contribute to a variety of structures (neural crest-derived cell types were mentioned earlier). The location of AP-2 signal in neural folds at 8.5 days (Fig. $4 C, D$ ) suggests that expression in neural crest cells begins prior to or coincident with their emigration.

In frontal sections of 9.5-dpc embryos, AP-2 mRNA continued to persist in surface ectoderm (pre-epidermis) and was pronounced in cephalic mesenchyme (Fig. 5A). The latter consists predominantly of midbrain- and hindbrain-originating neural crest cells that are forming rostral and branchial arch mesenchymal populations and dorsolateral ganglioblast aggregations (cranial ganglia primordia) adjacent to the hindbrain. The prominent lateral regions of AP-2 expression seen in Figure 5A are consistent with the trigeminal and facial-acoustic ganglia primordia (left) and branchial arch mesenchyme slightly ventral to ganglia primordia (right) (Altman and
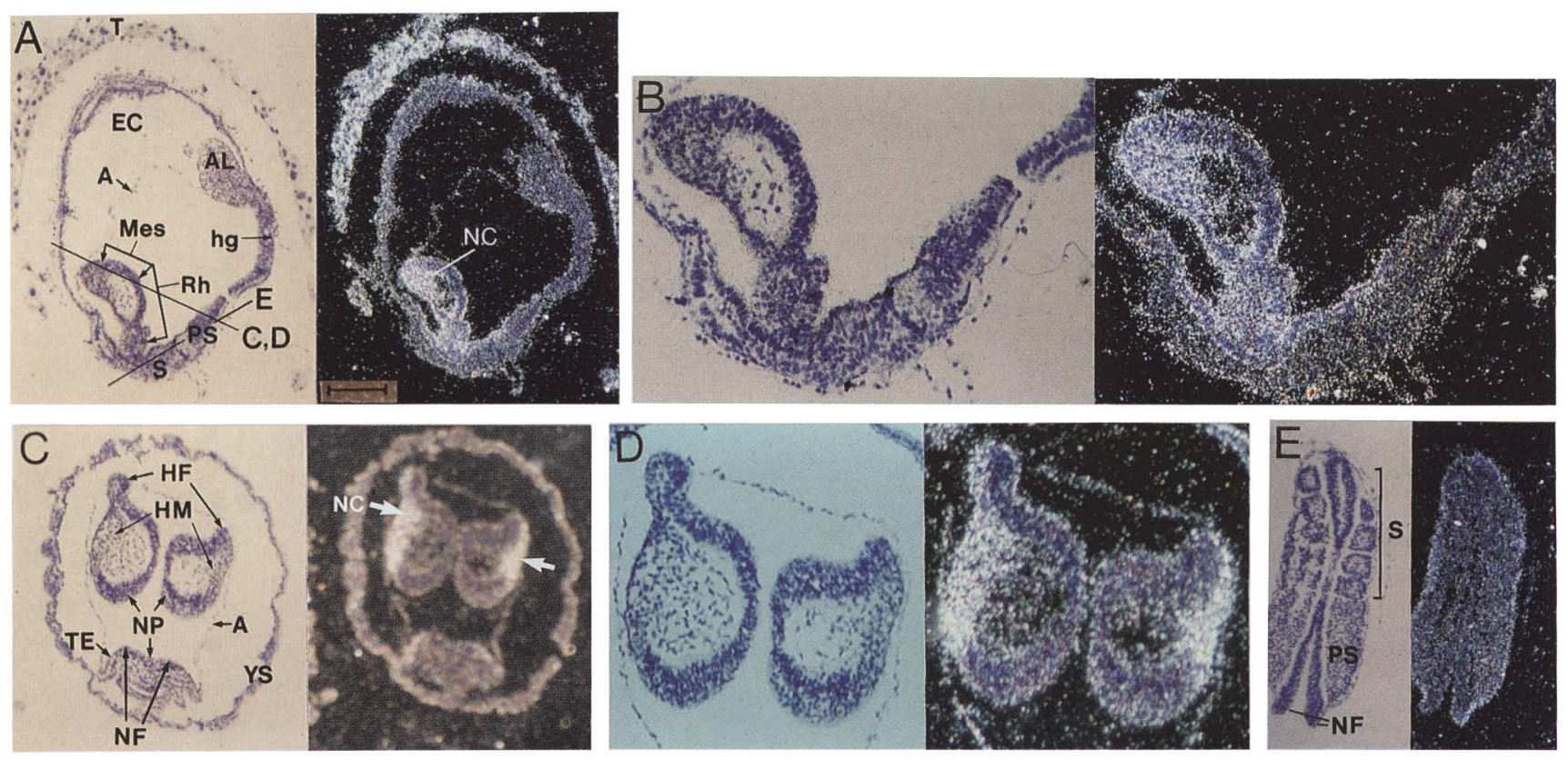

Figure 4. RNA in situ hybridization to 8.5 -dpc mouse embryo sections. Serial paraffin sections $(6 \mu \mathrm{m})$ hybridized with AP-2 antisense probe B240 (Fig. 1B) were photographed with bright-field illumination (left) to indicate morphology and dark-field illumination (right) to show hybridization signals. Toluidine blue-stained cell nuclei are visible in bright field; probe-specific hybridization signals (silver grains) appear white in dark field. (A) Lateral sagittal (longitudinal) section showing embryo and extraembryonic tissues. The diagonal lines represent the approximate planes of sections in $C-E$. $(B)$ Close-up of $A$ showing head and upper body of embryo. $(C)$ Section passing coronally through the brain and transverse through the posterior neural plate in a presomitic region (dorsal is up; for orientation, see $A)$. (D) Close-up of head region in $C$. (E) Frontal section through mid-body region showing neural tube and somites (S). (Mes) Mesencephalon (midbrain); (Rh) rhombencephalon (hindbrain); (S) approximate location of anterior-most somite; (PS) presomitic mesoderm; (hg) hindgut pocket; (AL) allantois; (A) amnion; (EC) extraembryonic coelom; (T) trophoblastic cells; (NC) presumed cranial neural crest cells; (HF) head neural folds; (HM) head mesenchyme; (NP) neural plate; (NF) neural folds; (TE) lateral thin ectoderm (presumptive epidermis); (YS) yolk sac. 
Bayer 1982; Chan and Tam 1990; Couly and LeDouarin 1990). Sensory neurons that arise in the trigeminal and facial-acoustic ganglia and motor neurons that pass through the ganglia will innervate mandibular and hyoid arch-derived facial structures via cranial nerves V, VII, and VIII. At this time, AP-2 was also expressed at low levels in mesonephric regions, in pericardial tissues, and diffusely around the dorsal aorta, gut, and lateral body and in limb bud mesenchyme (sections not shown).

At $10.5 \mathrm{dpc}$, AP-2 signal was evident in the dorsal root ganglia (DRG) (Fig. 5D,G). DRG develop from neural crest cells that aggregate segmentally on either side of the spinal cord in register with the somites; these spinal sensory ganglia are related to the more specialized cranial ganglia to which neural crest cells contribute (Le Douarin and Smith 1988). Frontal sections passing through the head identified continued strong AP-2 expression in the epidermis, trigeminal ganglia, and regions of facial mesenchyme heavily populated by neural crest cells (Fig. 5F). AP-2 signal was also evident in the 10.5-dpc embryo spinal cord (Fig. 5G).

In 11.5-dpc embryos, AP-2 mRNA persisted in the same structures as at $10.5 \mathrm{dpc}$, and several new sites of expression were also observed (Fig. 6). High AP-2 expression was seen in a continuous longitudinal region of the CNS extending at least as far anteriorly as the hindbrain-midbrain junction (Fig. 6A,B) and posteriorly in the spinal cord to at least the level of the hind limbs (Fig. $6 \mathrm{C}, \mathrm{D})$. Transverse views of the spinal cord and hindbrain showed that this AP-2-expressing column was mediolateral and mainly dorsal to the sulcus limitans (Fig. 6C,D). The dorsal-most part of the expressing region coincided with the dorsal entry zone where developing axons of DRG sensory neurons enter the spinal cord. Similarly, in the hindbrain, the AP-2 column coincided with the area where boundary caps of cranial ganglia contacted the CNS (Fig. 6C, facial-acoustic ganglia; others not shown). The disposition of this CNS column suggests that it includes not only the discrete regions where developing axons of sensory neurons enter the CNS but also sensory nuclei (synaptic centers) and longitudinal tracts along which sensory fibers travel to reach these nuclei. Sensory nuclei and tracts typically develop in columns dorsal and lateral to the sulcus limitans, in contrast with motor nuclei, which are found in ventral-medial columns (Arey 1974; Hopper and Hart 1984). Our present data suggest that AP-2 expression in the lateral CNS may mature craniocaudally, as expression seems to be restricted to the hindbrain and anterior spinal cord at $10.5 \mathrm{dpc}$ (Fig. 5A,C, and sections not shown). At $11.5 \mathrm{dpc}$, AP-2 expression was also detected in sympathetic ganglia (SG, all neural crest cell derived), along spinal nerve paths between DRG and SG, and at low levels in cranial ganglia developing posterior to the otic vesicle (including the superior, petrosal, and nodose ganglia; Fig. 6B and sections not shown).

In 12.5-dpc embryos, AP-2 signal continued to be found in peripheral nervous system (PNS) ganglia, epidermis, and lateral CNS (Fig. 7). Expression in limb mesenchyme was concentrated distally (in the progress zone) and in a small medial patch (Fig. 7D). Strong AP-2 signal was evident in facial mesenchyme adjacent to nasal epithelia and along the nasal lacrimal groove (Fig. 7A-D), and in corneal layers of the eye (Fig. 7B) (the contribution of neural crest cells to the cornea has been noted in chick embryos; Le Douarin 1982). The transverse section in Figure $7 \mathrm{~B}$ shows AP- 2 mRNA on the right side of the head in the trigeminal ganglion (ophthalmic branch) and anterior metencephalon. Serial reconstruction showed that this slightly skewed section passes through the bottom of the right eye and middle of the left eye. The section most likely marks the anterior boundary of the continuous column of AP-2 expression in the lateral CNS (expression in the left trigeminal ganglion and metencephalon was observed several sections more posteriorly). The arc of AP-2 signal in the metencephalon extends from the dorsal alar region into the pons and is similar to the known migration path of alar plate neuroblasts and glioblasts that form the pontine nuclei. These become synaptic centers connecting the phylogenetically newest part of the cerebellar cortex with the newest part of the cerebral cortex for the coordination of muscular activity (Hopper and Hart 1984).

Sections passing more caudally through 12.5 -dpc metencephalon and myelencephalon regions showed AP-2 expression in alar regions (future cerebellum), in patches near the sulcus limitans (possibly corresponding to sensory nuclei and visceral efferent nuclei), and along pathways characteristic of alar cells migrating to form the olivary nuclei in the ventral myelencephalon /data not shown). The pattern of AP-2 expression in the hindbrain and spinal cord between 11.5 and $12.5 \mathrm{dpc}$ is consistent with expression in sensory nuclei and sensory tracts which, when taken together, constitute a more or less continuous longitudinal column caudal to the hindbrain-midbrain junction. Autonomic efferent neurons also develop in intermediolateral regions of the CNS (in general, visceral efferent nuclei), and it is possible that the AP-2-expressing zone in the lateral CNS may include some of these autonomic nuclei as well. In addition to the continuous lateral column of AP-2 expression in the CNS, AP-2 mRNA was also seen in limited portions of the mesencephalon and diencephalon at 12.5 dpc (Fig. 6D and sections not shown).

\section{Discussion}

Transcription factor AP-2 exhibits a novel expression pattern between 8.5 and 13.5 days of mouse embryogenesis and is restricted to a subset of ectodermal and mesodermal tissues. The principle part of this pattern is a remarkable summary of the movements and aggregations of the major neural crest cell lineages; AP-2 mRNA is present in neural folds and head mesenchyme of neural crest cell origin at $8.5 \mathrm{dpc}$ and subsequently in neural crest cell-populated tissues, which include PNS ganglia and facial and branchial arch mesenchyme where neural crest cells form connective tissue and bones. Appreciable AP-2 expression also occurs in epi- 
Mitchell et al.

dermal ectoderm, limb bud mesenchyme, mesometanephric regions, and a lateral portion of the CNS. AP-2 is not significantly expressed in mesoderm of the notochord, somites, or heart, which lie medial to the neural axis, or in a variety of endodermally derived organs and tissues (liver, lungs, gut, and yolk sac). This endodermal exclusion is reflected in vitro in a similar lack of appreciable AP-2 expression in endodermally fated F9 teratocarcinoma and HepG2 hepatoma cells (Lüscher et al. 1989).
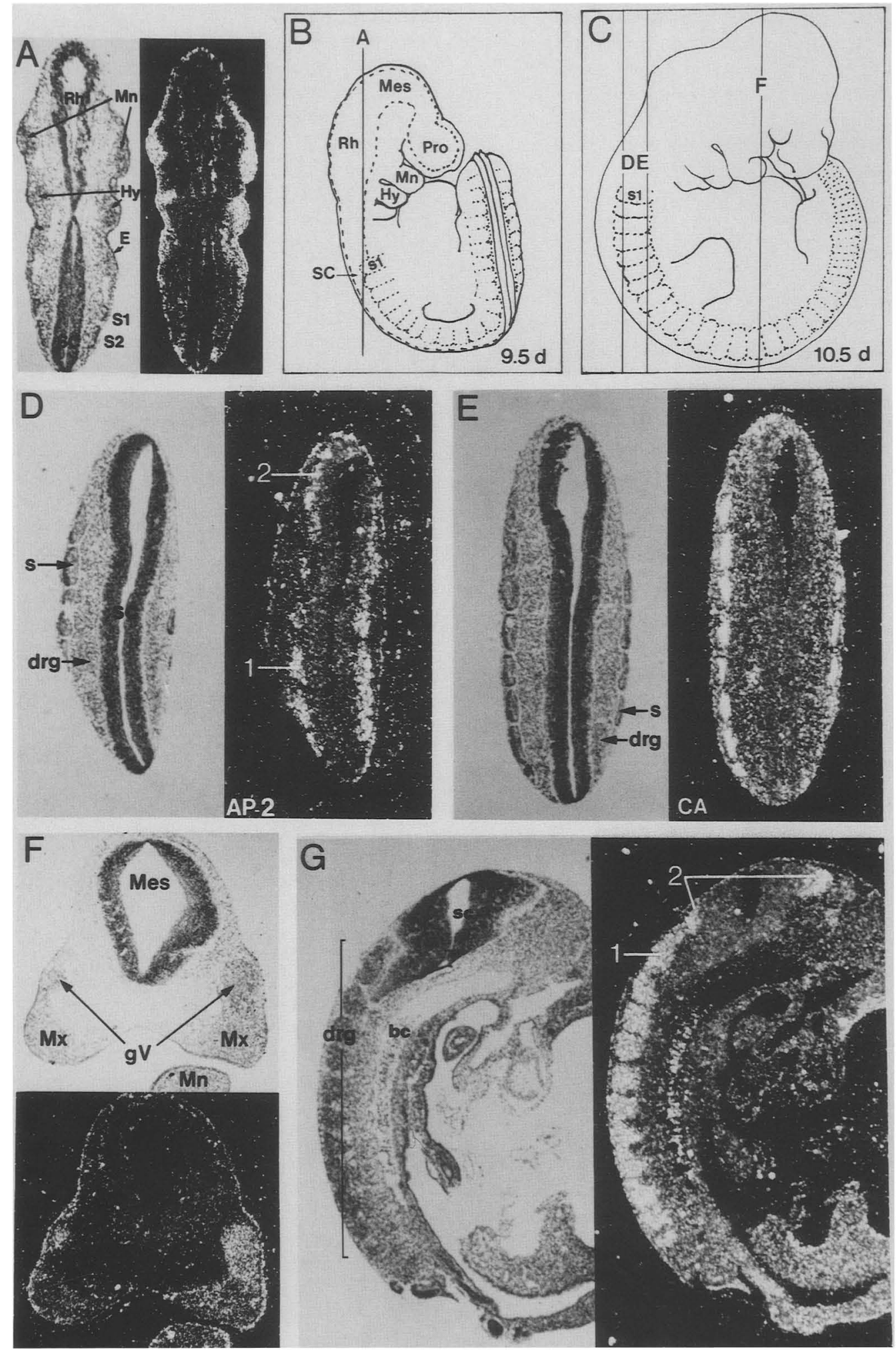

Figure 5. (See facing page for legend.) 
A potentially significant link between AP-2-expressing regions in the embryo is that they are all within tissues known to be developmentally sensitive to retinoid compounds. High concentrations of RA /acidic vitamin A) cause craniofacial, limb, nervous system, and primary body axis defects in vertebrate embryos (Wedden 1987; Wilde et al. 1987; Sive et al. 1990). The nature and severity of these defects are stage- and dosedependent and generally affect both ectodermal and mesodermal tissues. In young animals, lack of dietary vitamin A (retinol) or retinoid derivatives leads to skeletal and nervous system deficiencies, dry and thickened skin, kidney degeneration, and sterility in both sexes (Wolbach and Howe 1925). The pattern of expression of transcription factor AP-2 in the embryo is highly suggestive of a role for AP- 2 in regulatory programs during retinoid-sensitive morphogenic periods in many of the above mentioned tissues and structures.

\section{Expression in neural crest cells and other ectodermally derived tissues}

AP-2 expression in DRG is unambiguously neural crest lineage-specific as DRG contain cell types (sensory neurons, support cells, and Schwann cells) descended entirely from neural crest cells (LeDouarin 1982). In rostral and ventral craniofacial regions where AP- 2 mRNA is found, mesectodermal neural crest cells constitute the predominant mesenchymal cell type (especially between 8.5 and $10.5 \mathrm{dpc}$. These sites, together with the DRG, provide strong evidence that AP-2 is expressed in both neural and mesectodermal lineages of neural crest cells. In cranial ganglia $(\mathrm{CG})$, support cells are commonly held to be all neural crest-derived; however, sensory neurons in CG can originate from neural crest cells, placodal ectoderm, or both depending on the particular ganglia (D'Amico-Martel and Noden 1983; LeDouarin and Smith 1988). Thus, AP-2-expressing cells in CG are not necessarily of neural crest descent. However, although AP-2 is expressed in surface ectoderm as early as $8.5 \mathrm{dpc}$, it is not appreciably expressed in otic, olfactory, or epi- branchial placodes (data not shown). This suggests that AP-2 is turned off during differentiation of placodal ectoderm from surface ectoderm. In view of this, it seems more likely that AP-2-expressing cells in all CG are neural crest-derived neurons and/or support cells as in DRG.

High AP-2 expression occurs in the epidermis and the lateral CNS. Melanoblasts originate from neural crest cells and begin to migrate into future dermal regions as early as $8.5 \mathrm{dpc}$ in the mouse but are not believed to invade the epidermis until several days later. Thus, AP-2 signal in surface ectoderm at $8.5 \mathrm{dpc}$ is not likely to be contributed by melanoblasts. As persistent AP-2 expression in multiple neural crest cell lineages is already evident, it is reasonable to ask whether there is a fundamental ectodermal lineage relationship that links AP-2expressing cell types in surface ectoderm, neural fold neuroepithelia, and the lateral CNS. Single cell in situ labeling has identified individual precursor cells in the neural plate of early somite chick embryos that generate both neural crest cells and a sister lineage of neural cells that remain in the CNS (Bronner-Fraser and Fraser 1989). Whether the latter cells proliferate and come to populate a specific region of the CNS after neural tube closure (such as the lateral CNS region where AP-2 is expressed by $10.5 \mathrm{dpc}$ ) is not known. Another fate mapping experiment in the chick has indicated that, even as late as the 3-somite stage ( 8 -dpc mouse embryo), neural fold epithelia in the anterior head still harbors some cells destined to form surface ectoderm in the face (Couly and LeDouarin 1990). These experiments underscore potential lineage relationships between epidermal, neural crest, and CNS progenitor cells within or near the margins of the neural plate at this time.

\section{Expression in mesodermal tissues}

AP-2 transcripts are detected in a subset of mesodermal tissues that include facial and limb bud mesenchyme and mesometanephric regions. In keeping with the observed expression of AP-2 in embryonic nephric tissues,

Figure 5. RNA in situ hybridization to 9.5- and 10.5-dpc mouse embryo sections. Dark-field views show AP-2 expression, except $E$, which shows cardiac actin expression. (A) A 9.5-dpc frontal section showing dorsolateral AP-2 expression in head region. Anterior is up. (Right) Arrows indicate dorsolateral aspects of mandibular $(\mathrm{Mn})$ and hyoid $(\mathrm{Hy})$ arches (first and second branchial arches); (left, slightly more dorsal than the right), arrows indicate primordia of trigeminal and facial-acoustic ganglia for cranial nerves $\mathrm{V}$ and VII and VIII, respectively. (Rh) Rhombencephalon; (SC) spinal cord; (S1 and S2) first and second somites; (E) epidermis. (B) Sagittal representation of 9.5-dpc embryo; the vertical line shows the approximate plane of section in $A$. By 9.5 dpc (21-29 somite stage), the embryo has twisted around to assume the characteristic C-shaped fetal position with ventral surfaces facing inward (a process termed rotation that begins at $8.5 \mathrm{dpc}$ ) (Rugh 1968; Theiler 1972). The dashed line indicates contours of the neural tube; somites are indicated by dotted outline. (Pro) Prosencephalon (forebrain); (Mes) mesencephalon. (C) Sagittal representation of 10.5-day embryo; vertical lines show approximate planes of sections in panels that follow. (D) Frontal section $10.5 \mathrm{dpc}$. Anterior is up; right side is slightly more dorsal than left. The section reveals AP-2 expression in DRG $(1, \mathrm{drg})$ of the PNS and diffusely in lateral neuroepithelium $(2$, lateral CNS; the anterior CNS here corresponds to the hindbrain-spinal cord junction). (S) somites. Note that blood cells (see bc in G) give rise to an artifact signal in dark field, which is most visible where they have accumulated in major blood vessels and the heart; this is not probe specific. (E) Frontal section from same series as $D$ (slightly ventral to $D$ ) hybridized with a cardiac actin antisense probe (CA) to identify the myotome compartment of somites(s) for reference. $(F)$ Frontal section $10.5 \mathrm{dpc}$ passing through the head at the level of the mouth and midbrain (Mes) showing AP-2 expression in maxillary (Mx, right and left upper jaws) and mandibular (Mn, right lower jaw only) mesenchyme and trigeminal ganglia (gV). The left side is slightly more anterior than the right; the major portion of the left $\mathrm{gV}$ lies below this plane. $(G)$ Parasagittal section through upper spinal cord and lateral body showing AP-2 expression in DRG (drg, 1 ) and lateral regions of the spinal cord (2) adjacent to DRG (drg). 

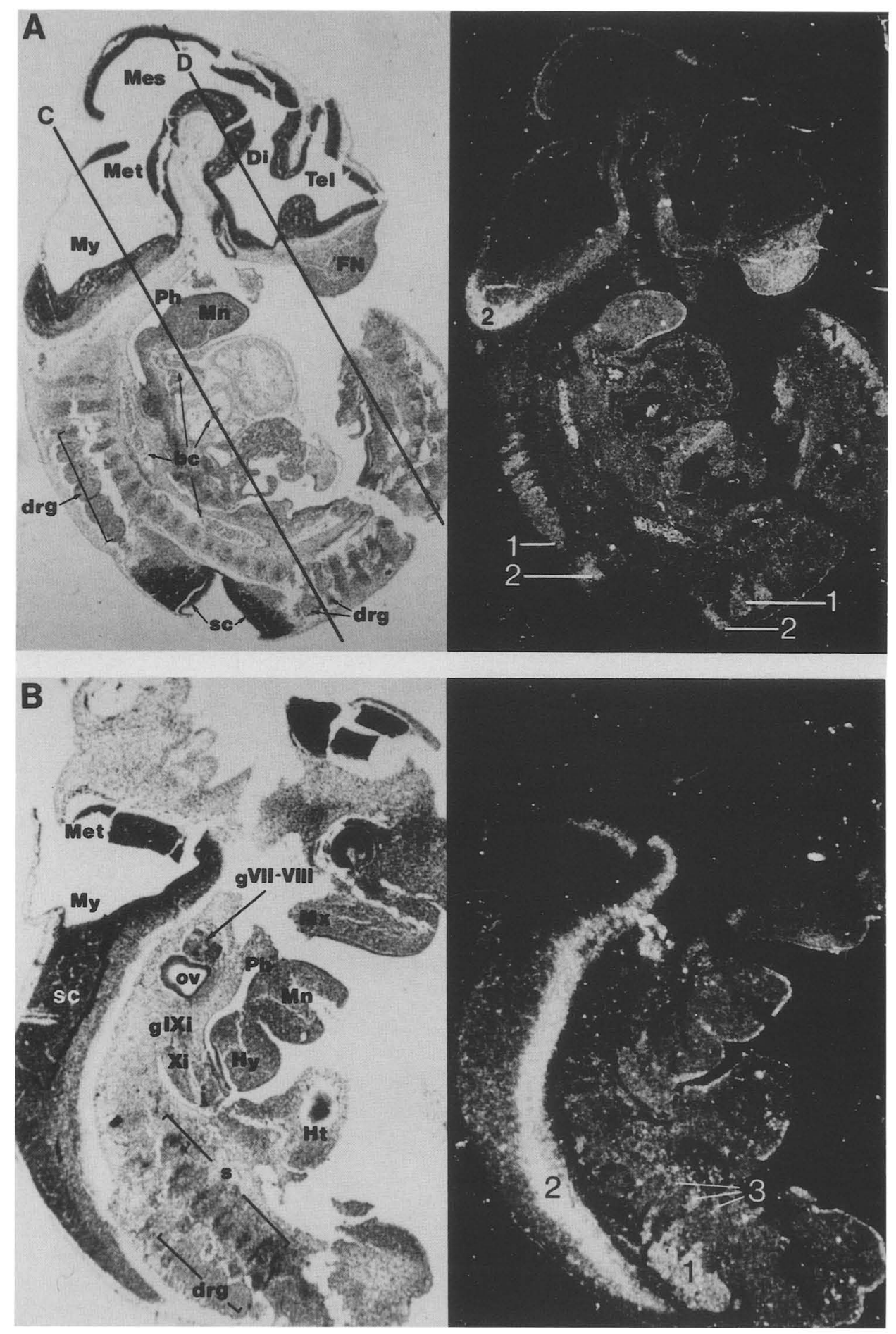

Figure 6. RNA in situ hybridization to 11.5 -dpc mouse embryo sections. AP-2 expression in DRG (1), lateral CNS (2), and sympathetic ganglia (3) is noted. Approximate planes for sections in $C$ and $D$ are shown in $A$. (A) Sagittal section showing expression in DRG, frontonaso-prominence (FN), and lateral portions of the myelencephalon (My, posterior hindbrain) and spinal cord (sc). [See note in Fig. 5D regarding artifact signal from blood cells $(\mathrm{bc})$.] (Tel) Telencephalon; (Di) diencephalon; (Met) metencephalon (anterior hindbrain); (Mes) mesencephalon; (Ph) pharynx; $(\mathrm{Mn})$ mandibular arch/tongue. (B) Parasagittal section through the lateral head and upper body, passing through the eye, mandibular $(\mathrm{Mn})$ and hyoid $(\mathrm{Hy})$ arches, pharynx, otic vesicle (ov, auditory vesicle), and heart (Ht). Dark-field views shows AP-2 signal in the lateral spinal cord and hindbrain (extending anteriorly to Met), in DRG (drg), sympathetic ganglia (3) near the heart, and facial-acoustic cranial ganglia (gVII-VIII) [part of signal here is due to extraneous material 


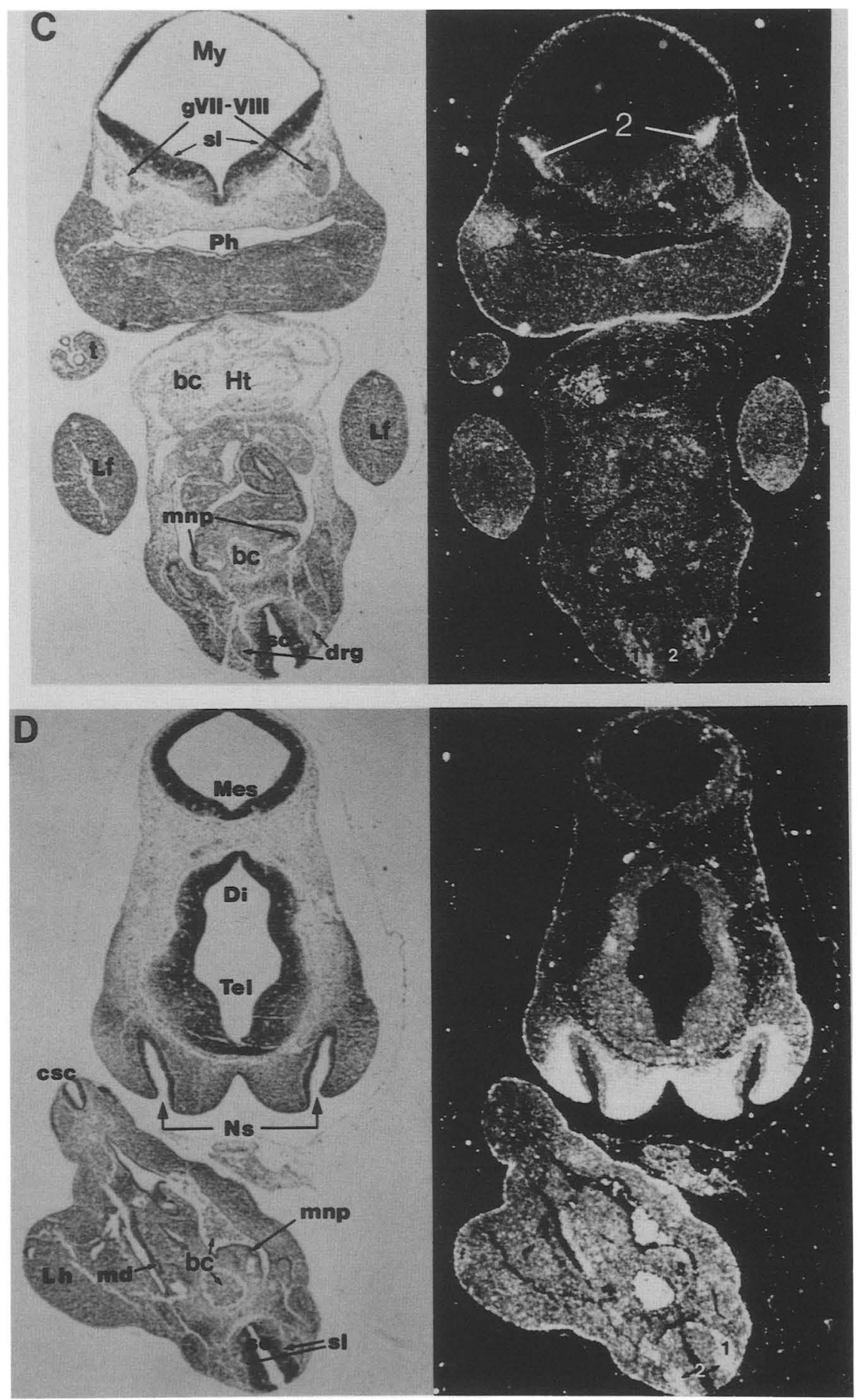

limited to this section (possibly torn from the adjacent hindbrain)]. Low, diffuse expression is seen in petrosal (gIXi) and nodose (gXi) (i, inferior) ganglia and along spinal and cranial nerve paths. Bright- and dark-field views in $B$ are adjacent serial sections. $\langle C|$ Frontal section showing expression in myelencephalon, facial-acoustic ganglia and their boundary caps apposing the myelencephalon (My), facial mesenchyme lateral to the pharynx, epidermis, spinal cord, drg, mesonephric regions (mnp), and forelimb buds (Lf). The lateral patches of AP-2 expression in the My are mediolateral and mainly dorsal to the sulcus limitans (sl), the slight indentation that marks the boundary between dorsal/sensory/alar plate and the ventral/motor/basal plate (in transverse views of the spinal cord in $C$ and $D$, the sulcus limitans is seen on the outer walls). (D) Frontal section showing AP-2 signal in facial mesenchyme, epidermis, DRG, spinal cord, mesonephric duct (md), and diencephalon. (Ns) Nostrils; (csc) spinal cord caudal to hindlimbs; (Lh) hindlimb bud. 
Mitchell et al.

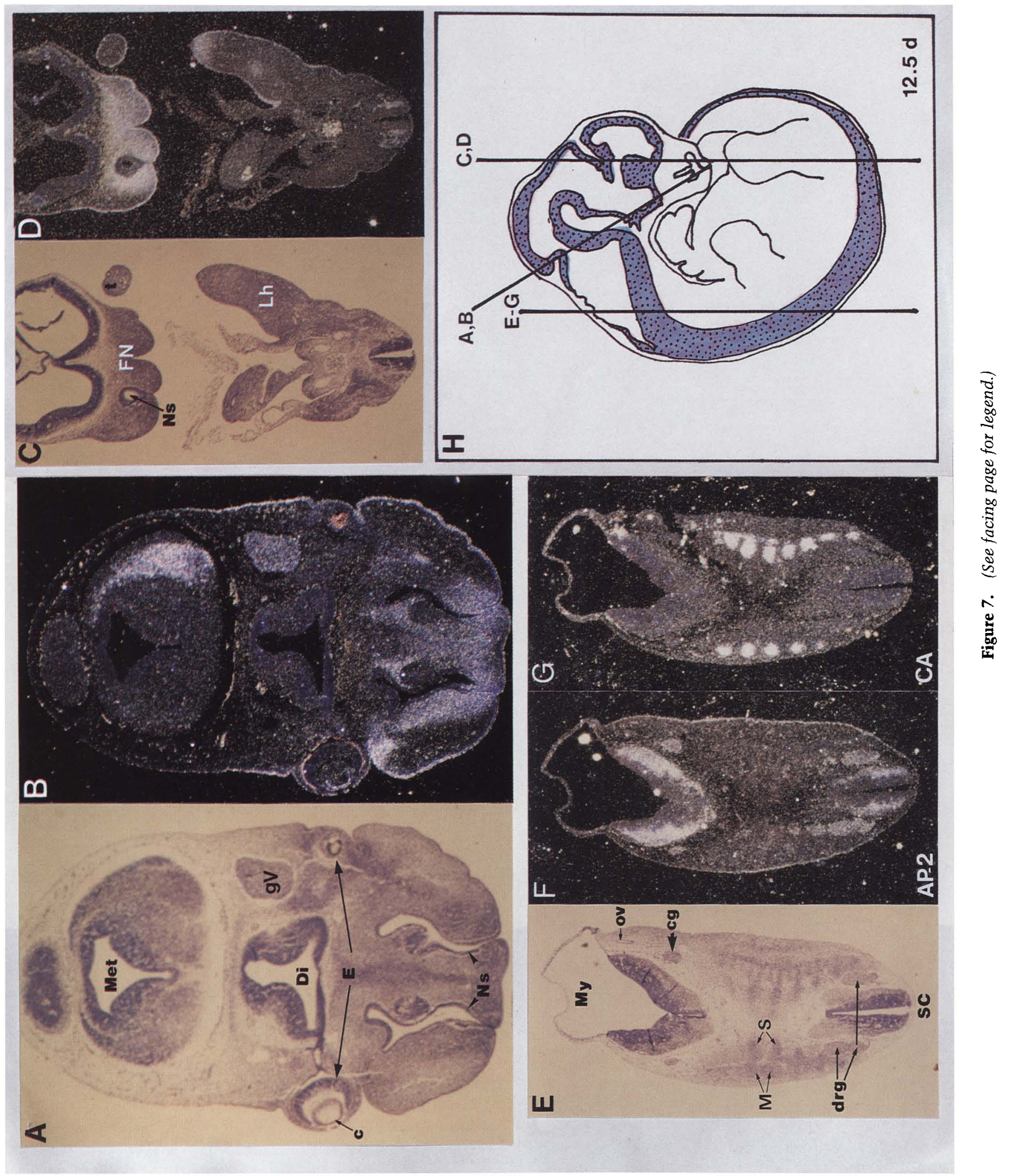


AP-2 mRNA is easily detected in cell lines derived from kidney (CV-1 and BSC-40 monkey kidney cells; P.J. Mitchell, unpubl.). HeLa cells, the human cell line in which AP-2 was first identified, were originally cultured from an epithelial carcinoma of the cervix. In the embryo, nephric and genital tract tissues develop in intimate association from urogenital ridge mesoderm. The mesonephros, which expresses AP-2, directly contributes tissue to the developing genital tracts of both males and females during its regression and replacement by the metanephros (adult kidney). Analysis of later embryonic stages and adult tissues to look for AP-2-expressing cells in developing or adult genital tracts may suggest whether AP-2 expression in HeLa cells is consistent with their tissue origin.

In the embryonic head, AP-2-expressing cells are nearly continuous from the lateral CNS, to CG, and out to facial mesenchyme and epidermis. Perhaps concerted AP-2 expression in these different ectodermal and mesenchymal cell lineages reflects the fact that they have inherited gene expression programs that are fundamentally coordinated for interactive morphogenetic processes during facial development and innervation. In facial mesenchyme, the distribution of AP- 2 mRNA is most consistent with expression in cranial neural crestderived mesectoderm, which will form skeletal elements and connective tissues in the face. In early limb buds, AP-2 mRNA is diffusely distributed throughout the mesenchyme, but by $12.5 \mathrm{dpc}$ it is concentrated at the distal end (progress zone) and in at least one small medial patch. Expression in limb epidermis is evident at all stages analyzed. A recent fate mapping experiment demonstrated that trunk level neural crest cells normally migrate into chick limb bud mesenchyme in detectable numbers (Serbedzija et al. 1990). These cells were considered likely to be Schwann cell precursors that associate with incoming neurons, which will innervate the limb. Although pre-Schwann cells could conceivably contribute part of the AP-2 signal in limbs, the pattern of AP-2 expression in limb bud mesenchyme, as in facial mesenchyme, is most consistent with expression in cells that are precursors to skeletal element- and connective tissue-forming cells.

A prevailing model of limb development asserts that RA is distributed in a morphogenic gradient emanating from a posterior part of the limb bud, the zone of polarizing activity (ZPA). Undifferentiated and actively di- viding mesenchymal cells in the distal progress zone receive cues from the limb apical ectodermal ridge (AER) which, when interpreted in the context of the RA gradient, render them competent to differentiate into a particular skeletal structure on being displaced proximally out of the progress zone (Eichele 1989; Summerbell and Maden 1990). As an outcome of this patterning process, appropriate skeletal elements of the limb develop in a proximodistal order. Morphogenesis of the limbs and the largely neural crest-derived frontonasal mass of the face are both notably sensitive to RA (Wedden 1987; Wilde et al. 1987; Eichele 1989|. Exposure to high concentrations of RA alters the normal patterning of skeletal elements in these sites causing truncation or duplication depending on the mode and time of exposure. Spatially and temporally, the expression pattern of AP-2 in the face and limbs is consistent with a role for AP-2 in regulatory programs that bring about patterning of skeletal elements in these regions.

The basic molecular principles that regulate retinoidsensitive morphogenetic processes are probably not far from being understood in rough outline (Eichele 1989; Summerbell and Maden 1990). An important part of this control is mediated by intracellular RARs, which are sequence-specific DNA-binding transcriptional regulators (Evans 1988; Green and Chambon 1988). RARs and other retinoid-binding cellular proteins that may be involved in mediating morphogenetic effects of retinoids are distributed in complex patterns in vertebrate embryos (Dollé et al. 1989a; Perez-Castro et al. 1989; Ruberte et al. 1990). Additional regulators of gene expression that have been implicated in retinoid-affected processes include Hox genes (Dollé et al. 1989b; Kessel and Gruss 1990; Wilkinson and Krumlauf 1990). Like AP-2, many of the murine Hox genes are first expressed between 7 and $8.5 \mathrm{dpc}$, reach peak levels in mid-embryogenesis, and are expressed region specifically in, among other places, continuous longitudinal compartments of the CNS with discrete anterior boundaries (Kessel and Gruss 1990). Also like AP-2, many of the Hox genes are demonstrably induced by RA treatment of NT2 teratocarcinoma cells, and the varying kinetics of RA induction for different Hox family members supports the idea that they could be differentially regulated by endogenous retinoids in the embryo (Simeone et al. 1990; Stornaiuolo et al. 1990). Other indirect evidence suggesting that Hox genes may be involved in regulating retinoid-

Figure 7. RNA in situ hybridization to 12.5 -dpc mouse embryo sections. Dark-field views show AP-2 expression, except $G$, which shows cardiac actin expression. (A) Transverse-frontal head section passing through the eyes (E), nasal chambers (Ns), anterior metencephalon (Met), diencephalon (Di, optic recess), and right trigeminal ganglion (gV, opthalmic branch). (B) Dark-field view of $A$ showing AP-2 expression in facial mesenchyme, the epidermis, $\mathrm{gV}$ and lateral metencephalon on the right side of the head, and cornea (c) of the eye. The pink color in the eyes is due to the pigment layer of the retina and is not related to probe hybridization. (C) Frontal section passing through lateral ventricles of telencephalon and through the body and right hindlimb bud (Lh). (FN) Frontonasal region; $(t)$ tail. $(D)$ Dark-field view of $C$. (E) Frontal section showing dorsal region between the myelencephalon (My) (the thin roof of the myelencephalon with choroid plexus is seen anteriorly) and the spinal cord (SC) approximately at the level of the forelimbs. (Cg) Cranial ganglia (probably jugular ganglion; gXs); $(\mathrm{ov})$ otic vesicle; $(\mathrm{s})$ somite schlerotome; $(\mathrm{m})$ somite myotome. $(F)$ Dark-field view of $E$. $(G)$ Dark-field view of a serial section close to section in $F$, which was hybridized with cardiac actin antisense probe (CA) to identify the somitic myotome. $(H)$ Diagrammatic representation of 12.5-day embryo in sagittal view showing approximate planes of sections in preceding panels. 
sensitive aspects of morphogenesis is found in transgenic mice that express Hox-1.1 ectopically (Balling et al. 1989). Nearly ubiquitous expression of Hox-1.1, normally not found in head regions, results in a spectrum of craniofacial defects resembling the teratogenic effects of RA.

\section{Target genes regulated by transcription factor AP-2}

The pattern of AP-2 expression in neural crest cells and the embryonic nervous system suggests that a major role for AP-2 may be in transcriptional regulation involved in establishing the PNS and its connections with the CNS. As the molecular mechanisms that generate positional regulatory information may be fundamentally similar for different morphogenetic or patterning events in the embryo, it is possible that the role of AP-2 in the nervous system is related to its role in the face, limbs, epidermis, and nephric system.

On the basis of current understanding of transcriptional activation, it is likely that target genes for AP-2 will vary in different parts of the embryo as a result of synergistic or antagonistic interactions between AP-2 and other region-restricted transcription factors or modifiers of AP-2 activity. By analogy to invertebrate systems where developmental regulatory hierarchies are at least superficially outlined, we suspect that AP-2 acts in regulatory cascades, that at least some of its target genes are other regulatory proteins, and that it may have negative as well as positive transcriptional effects on target genes. A location for AP-2 generally in middle stages rather than very early or terminal differentiation stages of developmental regulatory cascades is suggested by several observations. AP-2 appears to be dramatically activated between 7.5 and $8.5 \mathrm{dpc}$ of mouse embryogenesis, well beyond the initiation of gastrulation at $6.5 \mathrm{dpc}$. Expression peaks between 10.5 and $12.5 \mathrm{dpc}$, while many primordial organs and structures are being established, and then declines steadily thereafter. During induced differentiation of several types of cell lines in vitro, we find that AP-2 mRNA levels actually decline or are only transiently increased [unpublished observations with 3T3-L1 adipocytes and G7 and G8 myoblasts (P.J. Mitchell, unpubl.) and previous data on NT2 teratocarcinoma cells [Lüscher et al. 1989)]. Finally, expression levels in adult organs that we have tested are consistently lower than expression in embryonic or less differentiated cultured versions of these tissues. These findings suggest that in the ectodermal and mesodermal lineages where AP-2 is used, it may be more frequently involved in stem cell or precursor integrity and act during proliferative and determinative phases, rather than during terminal phases of differentiation.

\section{Regulators of AP-2 expression}

The anterior location of AP-2 mRNA in 8.5-dpc embryos discounts most of the known Hox genes as positive activators of very early AP-2 expression; an exception may be $\operatorname{Hox} 7.1$, which exhibits some temporal and spatial overlap with AP-2 in the anterior head (Hill et al. 1989; Robert et al. 1989). The complex overlap between domains of expression for AP-2 and different Hox genes in more posterior regions of the embryo does not suggest any simple regulatory relationships between these factors. Similarly, the embryonic expression patterns of the known RARs and retinoid-binding proteins (Dollé et al. 1989b; Perez-Castro et al. 1989; Ruberte et al. 1990) overlap with that of AP-2 to different extents, and no straightforward regulatory relationships are immediately evident. Our previous analysis of NT2 teratocarcinoma cells suggested that the AP-2 gene was not a primary target for activation by RARs in these cells, as the kinetics of AP-2 mRNA appearance were more consistent with AP-2 being secondarily induced in an RA-activated regulatory cascade (Lüscher et al. 1989). The fact that AP-2 mRNA levels remained low throughout a 7-day RA treatment of F9 teratocarcinoma cells, which initially express $\operatorname{RAR} \alpha, \beta$, and $\gamma$ (Hu and Gudas 1990), also suggests that the AP- 2 promoter may not be directly regulated by RARs. However, as new RAR types and isoforms are still being characterized (Kastner et al. 1990; Mangelsdorf et al. 1990) and RARs may activate their target genes by synergistic interaction with other transcription factors of restricted distribution, the possibility that AP-2 is directly regulated by RARs in certain cell types cannot be excluded. A better understanding of the regulation of AP- 2 awaits more thorough analyses of the AP-2 gene and promoter.

\section{Future prospects}

In our present study we have identified regions where AP-2 transcripts are expressed in the mouse embryo between 7.5 and $13.5 \mathrm{dpc}$, a period that covers many of the major morphogenetic events of vertebrate embryogenesis. AP- 2 protein and transcriptional activity in the embryo may actually be more restricted than the RNA distribution pattern as a result of RNA processing, translational, or post-translational regulations operating in different cell types. Future experiments will be directed toward localizing AP-2 protein at the cellular level, identifying important target genes, dissecting the AP-2 gene promoter, and determining the effects of blocking AP-2 function in different regions of the embryo. Additional in situ studies with appropriate markers should enable a more thorough characterization of cell types expressing AP-2, including cells not specifically addressed in our present study such as neural crest derivatives in the adrenal medulla and other paraendocrine tissues. These and experiments to examine the relationships between AP-2 and other suspected developmental regulators may ultimately contribute to a better understanding of transcriptional regulation during vertebrate embryogenesis.

\section{Materials and methods}

Screening a murine igt10 cDNA library for AP-2 clones

A 45-nucleotide oligonucleotide 5'-GTCTGTGAACTCCT- 
TGCAIATCTGCTTGGTGGCIAGIAGCA TGTT-3' deduced from a 15-amino acid peptide sequence of human AP-2 (Williams et al. 1988) was end-labeled with [ $\left.{ }^{32} \mathrm{P}\right]$ ATP using T4 polynucleotide kinase. This probe was used to screen a $\lambda \mathrm{gt} 10$ cDNA library prepared from 12.5-day mouse embryo cDNA (Hauser et al. 1985). Procedures were essentially according to Benton and Davis (1977) with minor modifications; the final wash conditions were $48^{\circ} \mathrm{C}$ with $2 \times \mathrm{SST}+0.5 \% \mathrm{SDS}$. A screen of $10^{6}$ plaques yielded a single murine AP- 2 cDNA clone, $\lambda 22$, containing a 635 -bp EcoRI insert that hybridized strongly to a full-length human AP-2 probe in a moderately stringent Southern blot analysis.

\section{DNA sequencing}

The 635-bp EcoRI insert from $\lambda 22$ and RsaI, AluI, and HaeIII fragments derived from it were sequenced after cloning into EcoRI-cut pBluescript-KS/SK (Stratagene) or SmaI-cut M13mplo using the dideoxy-nucleotide method (Biggin et al. 1983). A 40-bp segment at one end of the 635-bp EcoRI insert of $\lambda 22$ is not homologous to sequences in human AP-2. This short segment, which is adjacent to the $5^{\prime}$-most portion of the mouse AP-2 sequence, most likely was appended as a cloning artifact during the construction of the $\lambda g t 10$ library because it is not protected in RNase protection experiments using adult or embryo mouse mRNAs (including RNA from 12.5-day embryos, which the $\lambda 22$ clone represents|.

\section{Cell culture}

F9 cells were grown on gelatinized tissue culture plates. The base medium for all cell lines was DME $+10 \%$ FCS. Trans-RA and dibutryl-cAMP were obtained from Sigma and used at $10^{-6}$ and $5 \times 10^{-5} \mathrm{M}$, respectively, in experiments with F9 cells.

\section{RNA preparation}

RNA from cultured cells was prepared as follows: Near-confluent plates were rinsed twice with cold PBS; cells were scraped with a rubber policeman into cold PBS, transferred to microfuge tubes on ice, and pelleted by a $30-\mathrm{sec}$ spin at halfmaximal speed in a microfuge. Cell pellets from $100-\mathrm{mm}$ plates were gently resuspended in $300 \mu \mathrm{l}$ of cold lysis buffer $+2 \mathrm{mM}$ vanadylribonucleotide complex (Sigma) [lysis buffer: $150 \mathrm{~mm}$ $\mathrm{NaCl}, 10 \mathrm{~mm}$ Tris $\mathrm{HCl}$ (pH 7.9), $1.5 \mathrm{~mm} \mathrm{MgCl}_{2}, 0.65 \% \mathrm{NP}-40$ ] by pipetting three to four times and vortexing for $5 \mathrm{sec}$. Tubes were incubated 3-4 min on ice before pelleting nuclei by spinning $30 \mathrm{sec}$ in a microfuge. The supernatant was quickly transferred to a microfuge tube containing $220 \mu$ l Bonner buffer [ $7 \mathrm{M}$ urea, $350 \mathrm{~mm} \mathrm{NaCl}, 10 \mathrm{~mm}$ Tris $\mathrm{HCl}$ (pH 7.5), $10 \mathrm{~mm}$ EDTA, $1.4 \% \mathrm{SDS}$ ] and vortexed. RNA was prepared by two extractions with $\mathrm{dH}_{2} \mathrm{O}$-saturated phenol, one extraction each with phenol/ chloroform and chloroform, followed by ethanol precipitation. Adult mouse tissues and organ RNAs were obtained from Clonetech Laboratories, or were the kind gifts of J. Saffer and M. Annarella. Mouse embryo tissue RNAs were prepared by homogenizing embryos or dissected embryonic tissues in 10 volumes of $6 \mathrm{M}$ urea $/ 3 \mathrm{~m}$ lithium chloride, followed by overnight incubation at $4^{\circ} \mathrm{C}$, and subsequent pelleting of RNA by spinning $14,000 \mathrm{~g}$ for $1 \mathrm{hr}$. RNA was resuspended in $10 \mathrm{~mm}$ Tris- $\mathrm{HCl}(\mathrm{pH} 7.8)$ and $0.1 \mathrm{mM}$ EDTA $+0.5 \%$ SDS $+50 \mu \mathrm{g} / \mathrm{ml}$ proteinase $\mathrm{K}$ (freshly prepared buffer was preincubated for 10 $\min$ at $37^{\circ} \mathrm{C}$ ), incubated for $30 \mathrm{~min}$ at $37^{\circ} \mathrm{C}$, phenol/choroformextracted until the interface was clear, chloroform-extracted once, and EtOH-precipitated after addition of one-tenth volume of NaOAc. Poly $(\mathrm{A})^{+}$RNA was isolated from total embryo RNA by oligo(dT)-cellulose chromatography.

\section{Plasmids for RNA probe synthesis}

Fragments cloned into pBluescript KS/SK vectors for radiolabeled RNA probe synthesis using T7 and T3 RNA polymerases were as follows. AP-2: The 165-bp RsaI fragment (R2) containing the $5^{\prime}$-most 143 bp of mouse AP- 2 sequences in the $\lambda 22$ insert was taken as a BamHI-EcoRI fragment from an M13mpl0 clone used for DNA sequencing (see above); this was recloned into EcoRI + BamHI-cut pBS-KS. The resulting plasmid pKS-R2 was linearized with $E c O R I$ for AP-2 antisense probe synthesis with T7 RNA polymerase. The 22-bp non-AP-2 segment in the $\mathrm{R} 2$ probe does not interfere with the quantitation of AP-2 by RNase protection. However, in RNA in situ hybridization experiments, we observed that the $\mathrm{R} 2$ probe gave substantially higher background signal compared with similar exposure times with two other AP-2 antisense probes. Other AP-2 fragments: The 240-bp BglII fragment of mouse AP-2 was cloned into the BamHI-cleaved pBS-SK to make pB240; the 340-bp BglII-EcoRI fragment was cloned into BamHI-EcoRIcleaved pBS-KS to make pBR340. After appropriate linearization within polylinker regions, these plasmids were used to prepare B240 and BR340 AP-2 antisense and sense probes using T3 and T7 RNA polymerases, respectively. Spl: Approximately 220-bp PstI-BamHI fragment from pllmuSpl was subcloned into PstI-BamHI-cleaved pBS-KS; the resulting plasmid, pKSSplPB, was linearized with PstI for antisense probe synthesis with T7 RNA polymerase. Hox-2.1: A 390-bp PvuII-XbaI fragment from the EcoRI insert of $\lambda 6.8$ (Hauser et al. 1985) was cloned into HincII-XbaI-cleaved pBS-KS; the resulting plasmid, pKS- $\lambda 6 \mathrm{XP}$ was linearized with $\mathrm{Xhol}$ for antisense probe synthesis with T7 polymerase. Dhfr: A 450-bp PstI-BamHI fragment from pDHFR21 (Chang et al. 1978) was cloned into PstIBamHI-cleaved pBS-KS; the resulting plasmid KS-DHFR.PB was cut with $\mathrm{HpaII}$ for antisense probe synthesis with $\mathrm{T} 7$ polymerase.

\section{Preparation of RNA probes and RNase protection analysis}

$\left[\alpha^{-32}\right.$ P]UTP RNA probes were prepared and RNase protection analysis was performed essentially as described by Lüscher et al. (1989).

\section{RNA in situ hybridization to mouse embryo sections}

$\mathrm{CBA} / \mathrm{Ca}$ mice were mated, and embryos were obtained from pregnant females by standard techniques (Hogan et al. 1986). Paraffin-embedded sections were prepared from paraformaldehyde-fixed embryos, and in situ hybridization was performed essentially as described by Wilkinson et al. (1987). [ $\alpha^{-35}$ S]UTPlabeled antisense and sense RNA probes were prepared by $\mathrm{T} 7$ and T3 polymerase-directed synthesis using linearized pBluescript plasmids. When hybridized to adjacent serial sections, B240 and BR340 AP-2 antisense probes (nonoverlapping probes; Fig. 1B) identified similar region-specific AP-2 expression; however, the B240 probe consistently yielded the lowest background (this could be related to the presence of a GC-rich tract in the 3 -untranslated portion of AP-2 in BR340). Results shown here were obtained with the B240 probe. The mouse cardiac actin probe (Sassoon et al. 1988) protects a 50-bp segment in the $5^{\prime}$-untranslated portion of cardiac actin. Hybridizations were done at $55^{\circ} \mathrm{C}$ for $16 \mathrm{hr}$, and washes were performed at high stringency. Slides were coated with Ilford Nuclear Research Emulsion, and autoradiographic exposures were done for 5-7 days. Negative results with AP-2 sense control probes demonstrated the specificity of our in situ probes; and RNase protection analysis of RNA purified from 13.5-dpc embryo parts pro- 
vided a stringent complementary assay that was consistent overall with the region-specific pattern of AP-2 expression documented by our RNA in situ analysis.

\section{Acknowledgments}

We thank Michael Frohman, David Wilkinson, Beni Lüscher, Robb Krumlauf, Roger Morris, and members of the Rigby Laboratory for useful discussions; Marcus Noll for helpful comments on the manuscript; Adam Park for technical assistance with cell culture; Craig Hauser for the 12.5-dpc mouse embryo cDNA library and the murine Hox-2.1 cDNA clone; Trevor Williams for the 45-nucleotide human AP-2 guess-mer; Jeff Saffer for pmul1Spl prior to publication; Fritz Ochsenbein for photographic assistance; and Professor Aileen Silver for an earlier introduction to neural crest cells.

The publication costs of this article were defrayed in part by payment of page charges. This article must therefore be hereby marked "advertisement" in accordance with 18 USC section 1734 solely to indicate this fact.

\section{References}

Affolter, M., A. Schier, and W.J. Gehring. 1990. Homeodomain proteins and the regulation of gene expression. Curr. Opin. Cell Biol. 2: 485-495.

Akam, M. 1989. Hox and HOM: Homologous gene clusters in insects and vertebrates. Cell 57: 347-349.

Altman, J. and S.A. Bayer. 1982. Development of the cranial nerve ganglia and related nuclei in the rat. Adv. Anat. Embryol. Cell Biol. 74: 1-87.

Arey, L.B. 1974. Developmental anatomy. W.B. Saunders, Philadelphia.

Balling, R., G. Mutter, P. Gruss, and M. Kessel. 1989. Craniofacial abnormalities induced by ectopic expression of the homeobox gene Hox-1.1 in transgenic mice. Cell 58: 337-347.

Benton, W. and R. Davis. 1977. Screening $\lambda$ gt recombinant clones by hybridization to single plaques in situ. Science 196: 180 .

Biggin, M., T.J. Gibson, and G.F. Hong. 1983. Buffer gradient gels and ${ }^{35} \mathrm{~S}$ label as an aid to rapid DNA sequence determination. Proc. Natl. Acad. Sci. 80: 3963-3965.

Bronner-Fraser, M. and S. Fraser. 1989. Developmental potential of avian trunk neural crest cells in situ. Neuron 3: 755766.

Chan, W.Y. and P.P.L. Tam. 1988. A morphological and experimental study of the mesencephalic neural crest cells in the mouse embryo using wheat germ agglutinin-gold conjugate as the cell marker. Development 102: 427-442.

Chang, A.C.Y., J.H. Nunberg, R.J. Kaufman, H.A. Erlich, R.T. Schimke, and S.N. Cohen. 1978. Phenotypic expression in E. coli of a DNA sequence coding for mouse dihydrofolate reductase. Nature 275: 617-624.

Cohlan, S.Q. 1953. Excessive intake of vitamin A as a cause of congenital anomalies in the rat. Science 117: 535-536.

Couly, G. and N. LeDouarin. 1990. Head morphogenesis in embryonic avian chimeras: Evidence for a segmental pattern in the ectoderm corresponding to the neuromeres. Development 108: 543-558.

D'Amico-Martel, A. and D. Noden. 1983. Contributions of placodal and neural crest cells to avian cranial peripheral ganglia. Am. J. Anat. 166: 445-468.

Dollé, P., E. Ruberte, P. Kastner, M. Petkovich, C.M. Stoner, L. Gudas, and P. Chambon. 1989a. Differential expression of genes encoding $\alpha, \beta$ and $\gamma$ retinoic acid receptors and CRABP in the developing limbs of the mouse. Nature 342: 702-705.

Dollé, P., J: Izpisua-Belmonte, H. Falkenstein, A. Renucci, and D. Duboule. 1989b. Coordinate expression of the murine Hox-5 complex homeobox-containing genes during limb pattern formation. Nature 342: 767-772.

Eichele, G. 1989. Retinoids and vertebrate limb pattern formation. Trends Genet. 5: 246-251.

Evans, R.M. 1988. The steroid and thyroid hormone receptor super family. Science 240: 889-895.

Gaunt, S.J. and P.B. Singh. 1990. Homeogene expression patterns and chromosomal imprinting. Trends Genet. 6: 208212.

Green, S. and P. Chambon. 1988. Nuclear receptors enhance our understanding of transcriptional regulation. Trends Genet. 4: 309-314.

Hall, B.K. 1988. The neural crest. Oxford University Press, England.

Hauser, C.A., A.L. Joyner, R.D. Klein, T.K. Learned, G.R. Martin, and R. Tjian. 1985. Expression of homologous homeo-box-containing genes in differentiated human teratocarcinoma cells and mouse embryos. Cell 42: 19-28.

He, X., M.N. Treacy, D.M. Simmons, H.A. Ingraham, L.W. Swanson, and M.G. Rosenfeld. 1989. Expression of a large family of POU-domain regulatory genes in mammalian brain development. Nature 340: 35-42.

Hill, R.E., P.F. Jones, A.R. Rees, C.M. Sime, M.J. Justice, N.G. Copeland, N.A. Jenkins, E. Graham, and D.R. Davidson. 1989. A new family of mouse homeo box-containing genes: Molecular structure, chromosomal location, and developmental expression of Hox-7.1. Genes Dev. 3: 26-37.

Hogan, B., F. Costantini, and E. Lacy. 1986. Manipulating the mouse embryo. Cold Spring Harbor Laboratory, Cold Spring Harbor, New York.

Hopper, A. and M. Hart. 1984. Foundations of animal development. Oxford University Press, England.

$\mathrm{Hu}$, L. and L.J. Gudas. 1990. Cyclic AMP analogs and retinoic acid influence the expression of retinoic acid receptor $\alpha, \beta$, and $\gamma$ mRNAs in F9 teratocarcinoma cells. Mol. Cell Biol. 10: $391-396$.

Kadonaga, J.T., K.R. Karner, F.R. Masiarz, and R. Tjian. 1987. Isolation of cDNA encoding transcription factor $\mathrm{Sp} 1$ and functional analysis of the DNA binding domain. Cell 51: $1079-1090$.

Kastner, P., A. Krust, C. Mendelsohn, J.M. Garnier, A. Zelent, P. Leroy, A. Staub, and P. Chambon. 1990. Murine isoforms of retinoic acid receptor $\gamma$ with specific patterns of expression. Proc. Natl. Acad. Sci. 87: 2700-2704.

Kessel, M. and P. Gruss. 1990. Murine developmental control genes. Science 249: 374-379.

Koplan, R., G. Traska, and E. Fuchs. 1987. Retinoids as important regulators of terminal differentiation: Examining keratin expression in individual epidermal cells at various stages of keratinization. I. Cell Biol. 105: 427-440.

Le Douarin, N. 1982. The neural crest. Cambridge University Press, England.

Le Douarin, N.M. and J. Smith. 1988. Development of the peripheral nervous system from the neural crest. Annu. Rev. Cell Biol. 4: 375-404.

Lonai, P. and A. Orr-Urtreger. 1990. Homeogenes in mammalian development and the evolution of the cranium and central nervous system. FASEB I. 4: 1436-1443.

Lüscher, B., P.J. Mitchell, T. Williams, and R. Tjian. 1989. Regulation of transcription factor AP-2 by the morphogen retinoic acid and by second messengers. Genes Dev. 3: 15071517.

Maderson, P. 1987. Developmental and evolutionary aspects of 
the neural crest. Wiley and Sons, New York.

Mangelsdorf, D.J., E.S. Ong, J.A. Dyck, and R.M. Evans. 1990. Nuclear receptor that identifies a novel retinoic acid response pathway. Nature 345: 224-229.

Mitchell, P.J. and R. Tjian. 1989. Transcriptional regulation in mammalian cells by sequence-specific DNA binding proteins. Science 245: 371-378.

Mitchell, P.J., C. Wang, and R. Tjian. 1987. Positive and negative regulation of transcription in vitro: Enhancer-binding protein AP-2 is inhibited by SV40 T antigen. Cell 50: $847-$ 861.

Murre, C., P.S. McCaw, H. Vaessin, M. Caudy, L.Y. Jan, Y.N. Jan, C.V. Cabrare, J.N. Buskin, S.D. Hauschka, A.B. Lassar, H. Weintraub, and D. Baltimore. 1989. Interactions between heterologous helix-loop-helix proteins generate complexes that bind specifically to a common DNA sequence. Cell 58: $537-544$.

Perez-Castro, A.V., L.E. Toth-Rogler, L. Wei, and M.C. NguyenHuu. 1989. Spatial and temporal pattern of expression of the cellular retinoc acid-binding protein and the cellular retinol-binding protein during mouse embryogenesis. Proc. Natl. Acad. Sci. 86: 8813-8817.

Robert, B., D. Sassoon, B. Jacq, W. Gehring, and M. Buckingham. 1989. Hox-7, a mouse homeobox gene with a novel pattern of expression during embryogenesis. EMBO $\mathrm{I}$. 8: $91-100$.

Ruberte, E., P. Dollé, A. Krust, A. Zelent, G. Morriss-Kay, and P. Chambon. 1990. Specific spatial and temporal distribution of retinoic acid receptor gamma transcripts during mouse embryogenesis. Development 108: 213-222.

Rugh, R. 1968. The mouse, its reproduction and development. Burgess Press, Minneapolis, Minnesota.

Sassoon, D.A., I. Garner, and M. Buckingham. 1988. Transcripts of $\alpha$-cardiac and $\alpha$-skeletal actins are early markers for myogenesis in the mouse embryo. Development 104: $155-164$.

Sassoon, D., G. Lyons, W.E. Wright, V. Lin, A. Lassar, H. Weintraub, and M. Buckingham. 1989. Expression of two myogenic regulatory factors myogenin and MyoD1 during mouse embryogenesis. Nature 341: 303-307.

Serbedzija, G.N., S.E. Fraser, and M. Bronner-Fraser. 1990. Pathways of trunk neural crest cell migration in the mouse embryo as revealed by vital dye staining. Development 108: $605-612$.

Simeone, A., D. Acampora, L. Arcioni, P.W. Andrews, E. Boncinelli, and F. Mavilio. 1990. Sequential activation of HOX2 homeobox genes by retinoic acid in human embryonal teratocarcinoma cells. Nature 346: 763-766.

Sive, H.L., B.W. Draper, R.M. Harland, and H. Weintraub. 1990. Identification of a retinoic acid-sensitive period during primary axis formation in Xenopus laevis. Genes Dev. 4: 932942.

Stornaiuolo, A., D. Acampora, M. Pannese, M. D'Esposito, F. Morelli, E. Migliaccio, M. Rambaldi, A. Faiella, V. Nigro, A. Simeone, and E. Boncinelli. 1990. Human HOX genes are differentially activated by retinoic acid in embryonal carcinoma cells according to their position within the four loci. Cell Differ. Dev. 31: 119-127.

Sulik, K.K., C.S. Cook, and W.S. Webster. 1988. Teratogens and craniofacial malformations: Relationships to cell death. Development (suppl.) 103: 213-232.

Summerbell, D. and M. Maden. 1990. Retinoic acid, a developmental signalling molecule. Trends Neurosci. 13: 142-147.

Tan, S.S. and M. Morriss-Kay. 1986. Analysis of cranial neural crest cell migration and early fates in postimplantation rat chimaeras. J. Embryol. Exp. Morphol. 98: 21-58.
Tapscott, S.J., R.L. Davies, M.J. Thayer, P. Cheng, H. Weintraub, and A.B. Lassar. 1988. MyoD1: A nuclear phosphoprotein requiring a $\mathrm{Myc}$ homology to convert fibroblasts to myoblasts. Science 242: 405-411.

Theiler, K. 1972. The house mouse. Development and normal stages from fertilization to 4 weeks of age. Springer-Verlag.

Tickle, C., J. Lee, and G. Eichele. 1985. A quantitative analysis of the effect of all trans-retinoic acid on the pattern of chick wing development. Dev. Biol. 109: 82-95.

Wedden, S.E. 1987. Epithelial-mesenchymal interactions in the development of chick facial primordia and the target of retinoid action. Development 99: 341-351.

Wilde, S.M., S.E. Wedden, and C. Tickle. 1987. Retinoids reprogramme pre-bud mesenchyme to give changes in limb pattern. Development 100: 723-733.

Wilkinson, D.G., J.A. Bailes, and A.P. McMahon. 1987. Expression of the proto-oncogene int-1 is restricted to specific neural cells in the developing mouse embryo. Cell 50: 7988.

Wilkinson, D. and R. Krumlauf. 1990. Molecular approaches to the segmentation of the hindbrain. Trends Neurosci. 13: $335-339$.

Williams, T., A. Admon, B. Lüscher, and R. Tjian. 1988. Cloning and expression of AP-2, a cell-type-specific transcription factor that activates inducible enhancer elements. Genes Dev. 2: 1557-1569.

Wolbach, S.B. and P.R. Howe. 1925. Tissue changes following deprivation of fat soluble A vitamin. J. Exp. Med. 42: 753777. 


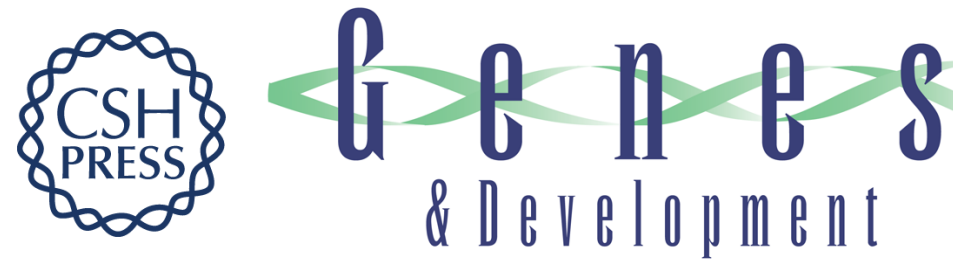

\section{Transcription factor AP-2 is expressed in neural crest cell lineages during mouse embryogenesis.}

P J Mitchell, P M Timmons, J M Hébert, et al.

Genes Dev. 1991, 5:

Access the most recent version at doi:10.1101/gad.5.1.105

References This article cites 53 articles, 22 of which can be accessed free at:

http://genesdev.cshlp.org/content/5/1/105.full.html\#ref-list-1

License

Email Alerting Receive free email alerts when new articles cite this article - sign up in the box at the top Service right corner of the article or click here.

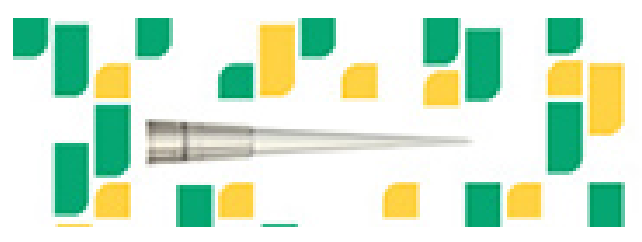

Focused on your science. 